\title{
School indicators of violence experienced and feeling unsafe of Dutch LGB versus non-LGB secondary students and staff, 2006 - 2010.
}

Citation for published version (APA):

Mooij, T. (2016). School indicators of violence experienced and feeling unsafe of Dutch LGB versus non-LGB secondary students and staff, 2006 - 2010. Journal of Interpersonal Violence, 31(20), 3413-3442.

https://doi.org/10.1177/0886260515585527

DOI:

10.1177/0886260515585527

Document status and date:

Published: 01/12/2016

Document Version:

Peer reviewed version

\section{Document license:}

CC BY-SA

Please check the document version of this publication:

- A submitted manuscript is the version of the article upon submission and before peer-review. There can be important differences between the submitted version and the official published version of record. People interested in the research are advised to contact the author for the final version of the publication, or visit the DOI to the publisher's website.

- The final author version and the galley proof are versions of the publication after peer review.

- The final published version features the final layout of the paper including the volume, issue and page numbers.

Link to publication

\section{General rights}

Copyright and moral rights for the publications made accessible in the public portal are retained by the authors and/or other copyright owners and it is a condition of accessing publications that users recognise and abide by the legal requirements associated with these rights.

- Users may download and print one copy of any publication from the public portal for the purpose of private study or research.

- You may not further distribute the material or use it for any profit-making activity or commercial gain

- You may freely distribute the URL identifying the publication in the public portal.

If the publication is distributed under the terms of Article 25fa of the Dutch Copyright Act, indicated by the "Taverne" license above, please follow below link for the End User Agreement:

https://www.ou.nl/taverne-agreement

Take down policy

If you believe that this document breaches copyright please contact us at:

pure-support@ou.nl

providing details and we will investigate your claim.

Downloaded from https://research.ou.nl/ on date: 26 Apr. 2023 


\title{
School indicators of violence experienced and feeling unsafe of Dutch LGB versus non-LGB secondary students and staff, 2006 - 2010
}

\author{
Ton Mooij \\ - Institute for Applied Social Sciences (ITS), Radboud University \& \\ - Faculty of Psychology and Educational Sciences (Welten Institute), Open University in \\ The Netherlands
}

\begin{abstract}
Gender and sexual orientation are expressed in heterosexual, lesbian (L), gay (G), bisexual (B), transgender (T), or queer $(\mathrm{Q})$ interests and behavior. Compared with heterosexual persons, LGBTQ persons seem to experience more antisocial behavior including negative discrimination and violence. To assess differences in LGBTQ related discrimination in schools the question for this research is: Do the degrees of violence experienced and feeling unsafe of LGBTQ students and staff in a school differ from those of non-LGBTQ students and staff in the same school? Secondary analysis was carried out on data from a Dutch national digital monitor survey on safety in secondary schools. In 2006, 2008, and 2010, participation amounted to 570 schools, 18,300 teaching and support staff, and 216,000 students. Four indicators were constructed at the school level: two Mokken Scale means assessing severity of violence experienced and two Alpha Scale means assessing feeling unsafe. Analysis of mean differences showed that LGB students experienced more violence and felt less safe than non-LGB students; LGB staff felt less safe in school than non-LGB staff. When LGB students experienced more violence at school than non-LGB students, LGB students also felt less safe than non-LGB students for all three years. No such relationships existed for LGB staff, or between LGB staff and LGB students. No significant relationships were found between the four LGB school indicators and contextual school variables. The outcomes and uniqueness of the study are discussed. Limitations are the use of secondary data and the operationalization of LGBTQ. Recommendations are made to improve assessment and promote prosocial behavior of students and staff in schools to reduce LGBTQ discrimination and violence.
\end{abstract}

\section{Introduction}

\section{Gender Non-Conformity and Discrimination at School}

Toomey, McGuire, and Russell (2012) define "heteronormativity" as "a societal hierarchical system that privileges and sanctions individuals based on presumed binaries of gender and sexuality; as a system it defines and enforces beliefs and practices about what is "normal" in everyday life" (p. 188). They report research in which students identified themselves as lesbian (L), gay (G), bisexual (B), transgender (T), or queer (Q) youth. These researchers use the term "queering" for "complex" identities (e.g., queer gender, queer sexuality). With LGBTQ or gender non-conformist participants, the numbers of social discrimination and antisocial or violent behaviors experienced was considered to be high (see Toomey et al., 2012). 
Much specific information can be found in research carried out by means of the 'National School Climate Survey' (NSCS) with a focus on school experiences of LGBTQ youth (Kosciw, Greytak, Bartkiewicz, Boesen, \& Palmer, 2012). Students in the USA can participate in this digital survey if they are at least 13 years of age and identify themselves as LGBTQ or have a gender identity other than male, female, or transgender (e.g., gender queer). In 2011, 8,584 LGBTQ students between the ages of 13 and 20 provided information about their school experiences. According to Kosciw et al. (2012), schools are hostile environments for LGBTQ students. They hear, for example, "gay" used in a negative way (84.9\%), homophobic remarks $(71.3 \%)$, or negative remarks about gender expression from other students $(61.4 \%)$ or from teachers or other staff $(56.9 \%)$ at school. They moreover feel unsafe because of their sexual orientation $(63.5 \%)$ or gender expression $(43.9 \%)$, are verbally $(81.9 \%)$ or physically harassed $(38.3 \%)$ or assaulted $(18.3 \%)$, or confronted with cyberbullying $(55.2 \%)$. The high incidence is exacerbated by school staff who rarely intervene on behalf of LGBTQ students. As a consequence, $60.4 \%$ of students who were harassed or assaulted do not report the incident to school staff because they believe little to no action will be taken, or the situation could even become worse if reported. LGBTQ students experiencing higher levels of victimization were three times as likely to have missed school in the past month than those experiencing lower levels (57.9\% vs. 19.6\%); they also demonstrate a lower level of academic success, educational aspirations, and psychological well-being.

Discrimination against gender non-conformity at school is an important research issue in many other countries too. In the UK, for example, percentages of bullying and violence against LGBTQ persons at school are comparable to those in the USA reported above (see Guasp, 2012; Hunt \& Jensen, 2007). Moreover, ethnographic or case research to better understand theoretical, practice, or prevention topics is carried out in countries such as the UK (McCormack \& Anderson, 2010; Perry \& Dyck, 2014), Australia (Mason, 1993), Sweden (De Boise, 2014), the Netherlands (Dankmeijer, 1994, 2011; Schouten, 2010), and the USA (Kelley \& Gruenewald, in press). In societies or situations where heterosexuality or a focus on the other gender or sex is normal, a person's self-identification as having a non-conforming gender or sexual orientation may conflict with the general beliefs and practices (Goldberg \& Meyer, 2012; Green, Dixon, \& Gold-Neil, 1993; Martino, 2000; Trotter, J. (2006). Gender non-conformity is then associated in particular with experiencing negative stereotypes, social discrimination, verbal abuse, social isolation, bullying, violence, and intolerance (Hebl, Bigazzi Foster, Mannix, \& Dovido, 2002; Yu, Xiao, \& Liu, 2013). Such incidents may occur early in an individual's career in elementary and secondary schools (Dunn, 2012; Gruenewald, 2012; Inspectie van het Onderwijs, 2009; Lee, 2002). Generally, the customary heterosexual pattern and dominance of hegemonic masculinity are seen as denying or reducing the respect for and acceptance of gender non-conformity interests and sexual minority behavior (Berrill, 1990; Cotten-Huston \& Waite, 2000; Gómez, Munte, \& Sorde, 2014; Herzog \& Rowley, 2014; Keuzenkamp, 2011).

\section{Possible Influences on Discrimination against Gender Non-Conformity at School}

To function well, schools should be secure places where all persons feel safe and do not encounter antisocial behavior, discrimination, violence, or harassment (Walls, Kane, \& Wisneski, 2010; Zimmer-Gembeck, Nesdale, McGregor, Mastro, Goodwin, \& Downey, 2013). Beauvais and Jenson (2002) and Carbines, Wyatt, and Robb (2006) qualitatively 
explore characteristics of social cohesion processes at school and identify many individual and school characteristics that seem relevant in indicating positive social interaction processes including the level of social cohesion at school. This also implies that social discrimination and antisocial behavior processes at school are complex and their possible causes may be manyfold (Caspersen \& Raaen, 2014; Han, Gallagher, Franz, Chen, Cabral, \& Marx, 2013; Harel-Fisch, Walsh, Fogel-Grinvald, Amitai, Pickett, Molcho et al., 2011; Tippett, Wolke, \& Platt, 2013).

In the Netherlands, for example, secondary students' motives underlying violent behavior are based in patterns reflecting discrimination with respect to the other person's physical appearance, behavior, level of school achievement, handicap, religious beliefs, gender, and sexual preference (Mooij, 2011a, 2012a). Concerning teachers, it has been shown that teachers in low-attainment secondary schools, who work in cities, are homosexual/lesbian, or do not feel at home in the country experience more violent behavior as victims or witnesses of negative discrimination than their respective counterparts (Mooij, 2011b). Moreover, school level characteristics related to the school's social climate and culture seem also relevant in LGBTQ-based discrimination and behavioral processes with both students and teachers. As McCormack and Anderson (2010) state: "At an institutional level, schools produce their own sexual and gendered oppression (...). Curricula, policies, and officially sanctioned discussion about sexuality have been shown to privilege heterosexuality while simultaneously dismissing all other sexual identities (...) to obtain a culturally validated form of masculinity, boys must socially distance themselves from gay students and (...) are often required to intellectualize homophobic attitudes" (p. 844-845; cf. also Kelley \& Gruenewald, in press).

In line with a school-related gender non-conformity or heteronormativity explanation, Kosciw et al. (2012) propose a number of strategic approaches and activities focusing on LGBTQ education, including anti-discrimination and violence prevention, for example, through Gay-Straight Alliances (GSA). A main characteristic of GSA is to combine concrete prosocial actions and various types of in-school support to realize positive social effects on students. Their suggestion is reflected in papers of authors of various countries (Dankmeijer, 2011; Fetner \& Kush, 2008; Russell, Muraco, Subramaniam, \& Laub, 2009; Schouten, 2011; Valenti \& Campbell, 2009; Walls et al., 2010). Toomey et al. (2012) conceptualize "queering of the educational system" as a means to ensure that school environments become safer for peers deviating from the hetero-normal gender and sexuality norms. This queering requires "that the curriculum, policies, and practices of schools are inclusive of all individuals and their experiences" (p. 188); cf. also Beauvais and Jenson (2002), Carbines et al. (2006), and Perry and Dyck (2014).

The degree of heteronormativity at school is then an indication of, but also one of the explanatory factors of gender non-conforming behavior concerning students and teachers. For an adolescent in a school characterized by a high level of heteronormativity, awareness of and self-identification as being gender non-conformist, including acceptance of being different from the heterosexual norm, may be hardly possible or take several years of serious emotional and social behavioral problems experienced with peers, friends, and family, and at school (Mooij \& Fettelaar, 2013a). For a professional teacher, comparable complicated or socially problematic processes of self-identification are particularly at stake when, at a school characterized by a high level of heteronormativity, he or she has to make a distinction 
between the personal identity ("me") and the social identity ("how do I present myself in school”); cf. Ferfolja (2010), Friesen and Besley (2013), and Magnusson and Allen (1983).

\section{School level concepts and their relationships}

The studies by, for example, Guasp (2012), Hunt and Jensen (2007), Kosciw et al. (2012), and Toomey et al. (2012) indicate the types of violence experienced by LGBTQ adolescents at the individual level. It is not known to what degree these violence rates are characteristic for LGBTQ students and LGBTQ staff compared with non-LGBTQ students and non-LGBTQ staff in the school. Schools differ in their degrees of violence experienced by students and staff (Mooij, in press) whereas the degree of violence experienced by LGBTQ persons may or may not deviate from the degree of violence experienced by the other or non-LGBTQ persons in the same school. A comparable statement applies to the feelings of safety of students and staff at a specific school. In other words, degrees of violence and feeling unsafe can function as school specific indicators of LGBTQ discrimination against gender non-conformity. The more LGBTQ indicators at school level are relevant in explaining social discrimination processes, the more it would be wise to try to reduce discriminatory or antisocial behavior or violence as a characteristic of the school and its social culture as such, instead of only focussing on antisocial behavior of one or more students or teachers.

This line of theorising results in the acknowledgement of four concepts that are important to estimate whether indicators of violence and feeling safe of persons in a specific school are influenced by being LGBTQ compared to being non-LGBTQ. The school level concepts indicate the extent to which LGBTQ staff, or LGBTQ students, experience more violence, or feel less safe at school than non-LGBTQ staff or non-LGBTQ students at the same school. These concepts are:

1. Mean of severity of violence experienced by LGBTQ staff compared with non-LGBTQ staff at the same school;

2. Mean of severity of violence experienced by LGBTQ students compared with non-LGBTQ students at the same school;

3. Mean of extent to which LGBTQ staff feel unsafe at school compared with non-LGBTQ staff at the same school;

4. Mean of extent to which LGBTQ students feel unsafe at school compared with non-

LGBTQ students at the same school.

In addition, as implicated in GSA research (Kosciw et al., 2012), other social, educational, cultural, and behavioral school variables may be related to the four LGBTQ school indicators. Different "contextual" school variables can then be explored for their relationships to the four LGBTQ school indicators. If demonstrated empirically, such relationships may reveal or reflect potential measures or strategies for conducting and evaluating school policy research for educating students and staff on social and cultural discrimination, threats to safety, or violence against LGBTQ persons at school (cf. Mooij, Sijbers, \& Sperber, 2006; Russell et al., 2009; Schuyf, 2009; Valenti \& Campbell, 2009; Walls et al., 2010).

A first series of these contextual variables concerns participation of a school in GSA and school mean results with respect to violence experienced and feelings of lack of safety of staff and students. All of these may be indicators of the more or less general social cohesion or social climate including LGB discrimination at the school (cf. Russell et al., 2009). In addition, secondary schools characterised by a higher track or level of educational attainment 
of students, or a higher percentage of first-grade students involved in the survey, may differ from other schools with respect to LGB discrimination. For example, it seems reasonable to expect that, as a school is characterised by a higher level of students' attainment in education, LGBTQ staff and LGBTQ students will experience relatively more safety and less violence at this school. Moreover, if acceptance of LGBTQ is related with a more mature personal development, schools that have a relatively higher percentage of younger students (e.g., firstgrade) are expected to report higher levels of violence toward LGBTQ staff and LGBTQ students compared to non-LGBTQ staff and students.

Furthermore, to explore the relevance of being religious, the percentage of students defining themselves as being religious is included. Also, the number of students at school seems relevant; although the common belief is that schools with lower numbers of students are more safe than other schools, in the Netherlands it has been demonstrated repeatedly that schools with lower numbers of students are less safe than other schools (Mooij, 2001). This is explained by the fact that smaller schools usually educate students with lower levels of attainment, or students with specific cognitive, social or emotional problems. Finally, a school may possess an official school policy to increase respect for LGBTQ persons at school. If a school does have such a policy, potential effects could be reflected in the school's relatively lower degree of violence and higher degree of feelings of safety reported by LGBTQ staff and LGBTQ students compared with non-LGBTQ persons.

\section{Research question}

Some information concerning the school heteronormativity concepts can be found in qualitative or explorative small-scale studies (e.g., Buijs, Hekma, \& Duyvendak, 2009; Espelage, Aragon, \& Birkett, 2008; Felten, 2008; Kamps, 2010; Van Wormer \& McKinney, 2003). However, large-scale and nationally representative quantitative information would enable the construction of more robust school level indicators of LGBTQ discrimination. Such information is, for example, available via national surveys on school safety conducted originally on behalf of the Dutch Ministry of Education, Culture, and Science. We can use data from these surveys to define and analyze to what degree indicators of violence and feeling safe in a specific school are influenced by being LGBTQ vs. non-LGBTQ. The research question that guided the current exploratory study is formulated as: Do the degrees of violence experienced and feeling unsafe of LGBTQ students and staff in a school differ from those of non-LGBTQ students and staff in the same school; if yes, what are the relationships between a) school indicators assessing LGBTQ discrimination against students and staff and b) these school indicators and other school characteristics?

\section{Method}

\section{The 'National School Safety Monitor Survey' (NSSMS)}

The Dutch Ministry of Education, Culture, and Science aims to support schools in enhancing the personal and professional qualities of teachers and support staff in order to optimally stimulate students' personal and academic development and learning. To assist schools in concrete ways, the Ministry also developed a national policy on school safety (cf. Mooij, 1994, 2001). Attention for the safety of LGBTQ persons in schools has been gradually integrated into national policy (cf. De Graaf, Van de Meerendonk, Vennix, \& 
Vanwesenbeeck, 2003; Mooij, 2007; Keuzenkamp, 2011; Keuzenkamp \& Oudejans, 2011). To be informed about the state of affairs and development of school safety at the national level, the Ministry initiated the development of a national survey ["National School Safety Monitor Survey", NSSMS], which has been administered every other year since 2006. The focus is on assessment of institutional, educational, curricular, social, behavioral, and socialpsychological aspects of school and different types of behavior including violence experienced by students, teachers, and support staff; moreover, NSSMS assesses various types of background characteristics of schools, school personnel, and students.

The NSSMS also obtains information about gender and having a gender conforming or non-conforming sexual orientation of each student and staff member. Secondary analysis of the data will enable a first assessment of the potential differences in LGBTQ related discrimination in schools. The focus can be directed on differences in the degrees of violence experienced and feeling unsafe among LGBTQ staff and students, and other staff and students, all within the same school.

In the development phase of the NSSMS, pilots were conducted to try out three digital questionnaires and a nationwide data collection procedure for students, teachers and support staff, and members of school management (cf. Mooij et al., 2006). Respondents' answers were given anonymously and provided information about the situation at specific schools, and participants' personal experiences in and around school since the most recent summer vacation. With each survey, the national data were checked for representativeness, reliability, and homogeneity (see Mooij et al., 2006; Mooij, De Wit, \& Fettelaar, 2011; Mooij, De Wit, \& Polman, 2008). Table 1 provides information on the number of participating schools, school managers, teaching and support staff, and students in 2006, 2008, and 2010.

Table 1 about here

Each assessment year, schools decided whether or not to participate in the survey. Therefore, at school level and at the individual level of staff and students, data collection was cross-sectional. Moreover, attention for GSA programs has evolved in the Netherlands since about 2010 which limits the availability of the data on such programs.

Schools that participate in the NSSMS receive feedback on their results including two-part diagnostic information. First, diagnostic information concerning cross-sectional outcomes about the school's actual results are compared with actual national or norm results; second, a longitudinal overview is given of this particular school's results for the primary concepts and variables for all the years that the school participated. This "double diagnostic" information (Mooij, 2013; Mooij \& Smeets, 2009) enables schools to empirically evaluate their own social and safety processes in differentiated ways. Moreover, they can identify issues related to their school safety policy and take appropriate action. A follow-up survey allows them to evaluate the steps they have taken.

\section{Variables and Operationalization at Individual Level}

Assessment of experiencing violence by staff and students

The NSSMS investigates "experience of violence" for 29 items covering self-reported incidents of six categories of violence (verbal, material, social, mild/moderate physical, severe physical, sexual). Students and teaching and support staff were asked to indicate to what 
extent they had experienced violence as a victim, a perpetrator, or a witness since the most recent summer vacation (cf. Ferfolja, 2010; Jackson, 1968; Mooij \& Fettelaar, 2013a; Willis, 1978). The item scores indicate the variation in a school's social climate or level of social cohesion which indicates the degree to which persons mutually behave in socially respectful and supportive ways (cf. Beauvais \& Jenson, 2002; Carbines et al., 2006; Kosciw et al., 2012; Toomey et al., 2012).

In a preliminary analysis step, we used the Mokken Scale Analysis (Mokken, 1997; Molenaar \& Sijtsma, 2000) to rank the scores on the 29 items from "least severe/most common" to "most severe/least common". The resulting "Mokken Scale on Severity of Violence Experienced" (MSSVE) meets all high-standard requirements for Mokken homogeneity, unidimensionality, and reliability (Mooij, 2012b). Moreover, item ranking is cumulative, which is an advantage compared to, for example, factor analysis: If a respondent's score is "yes" on a less common incident of violence, he or she will generally also score "yes" on items related to more common incidents.

Because some of the items were measured differently in 2006, the Mokken results for that year cannot be compared directly with those of 2008 and 2010. This study uses results on the MSSVE for teachers and support staff, which consists of 12 items (scale range 1 - 12) assessed in 2008 and 2010; see the item ranking and item frequencies (\% who have experienced the incident mentioned in the item) in Table 2. The reliability Rho of the MSSVE for staff is high (0.89) compared with the value which is required (at least 0.50; see Molenaar \& Sijtsma, 2000).

\section{Table 2 about here}

The severity of violence experienced by a staff member is determined by that person's total score for the 12-item scale. A personal score of 4 , for example, means that the staff member has experienced "talking in an extra loud voice," "making a lot of noise on purpose," "bothering someone on purpose," and "jabbing someone on purpose". This individual score represents a relatively low intensity on this scale.

Students were asked to score the same 29 items as staff on reported violence. Once again, the Mokken Scale Analysis was used to control for the reliability and unidimensionality of the items in 2008 and 2010 (Mooij, 2012b). The result was a cumulative MSSVE for students of 23 items (scale range $1-23$ ) ranging from "least severe/most common" to "most severe/least common". Table 3 shows the items, their ranking, and their frequency (\% who have experienced item). Again, the reliability Rho of the MSSVE is high (0.93-0.94). As with the results for staff, an individual score of 13 means that a student has experienced the incidents of violence described in items 1 through 13 in Table 3 since the most recent summer vacation.

Table 3 about here

\section{Assessment of feeling unsafe by staff and students}

Whether someone felt safe (or unsafe) at school was determined by looking at whether they felt safe or unsafe at seven different locations. These were: in the classroom, in a study room or office, in the corridors, in the cafeteria, in the toilets, in the entry hall/locker area, and in the schoolyard. In 2006, 2008, and 2010, these seven dichotomous items were analyzed for 
internal homogeneity using Cronbach's Alpha. The Alpha value for students was at least .88 across the three years; for teachers and support staff, it was at least .95. The seven items were combined in a scale that consists of the mean score of the items, indicating the individual degree of feeling safe at school (cf. Mooij, Smeets, \& De Wit, 2011).

\section{Direct assessment of sexual orientation with teaching and support staff}

With teaching and support staff, direct assessment or self-identification was used to collect information about their sexual orientation as a) heterosexual, b) lesbian or gay, or c) bisexual. Data on $\mathrm{T}$ or $\mathrm{Q}$ were not available. Table 4 presents percentages and numbers for the national surveys conducted in 2006, 2008, and 2010.

Table 4 about here

Non-responding numbers in Table 4 are relatively high. In the pilot phase of the digital survey, in particular, persons in religious schools appeared to have difficulties in answering this question (cf. Mooij et al., 2006). In discussing the problems with these respondents we noticed that not responding did not necessarily indicate that this person was gay or lesbian. Also, the use of forced choice answer alternatives in the digital procedure did not resolve these response difficulties.

\section{Indirect assessment of sexual orientation with students}

In the pilots to construct the digital questionnaires (Mooij et al., 2006), we started with direct assessment of sexual orientation with students in the same way we had done for staff. However, with adolescents aged about 12-18, this direct questioning could result in negative emotional reactions and controversy in which students, schools, and parents could become involved. In this secondary analysis, we therefore used an indirect measure of sexual orientation which was also included in the NSSMS questionnaires for staff and students. A staff member or student who had experienced violence as a victim could indicate one or more motives for the violence experienced since the most recent summer vacation. Student victims who stated that the violence they experienced took place "because I am gay/lesbian" or "because I am bisexual" were selected as being LGB. These are two out of a total of 16 motives that respondents could choose; other motives, for example, concerned appearance, background (ethnic minority as opposed to Dutch), being religious or non-religious, and being female or male. In the present context it is assumed that students who indicate they have been victims of violence motivated by their sexual orientation are, in fact, LGB. This indirect operationalization, however, excludes youth who are LGB but did not experience violence because of their sexual orientation and those who state they are not LGB and did not experience violence. As no alternative is available, we have to accept this potential selection bias and use this operationalization to compare all types of sexual orientation categories (which differs from surveys based only on persons who self-select and self-identify as LGBTQ, e.g., Toomey et al. (2012) and Kosciw et al. (2012)). 


\section{Variables and Operationalization at School Level}

School concepts assessing LGB discrimination

Aggregation of the individual violence and safety data per school enables the construction of analytic school level characteristics to assess school level concepts. These empirical indicators can be related also to other individual or school level variables (cf. Mooij \& Fettelaar, 2013b; Mooij, Smeets et al., 2011). The empirical score or value of an LGB school indicator was determined for each school by comparing the mean total scores of the school's LGB staff members or students to those of its non-LGB staff members or non-LGB students in the same school (Mooij, Fettelaar, \& De Wit, 2012). For example: school indicator $=$ school mean of violence experienced by LGB staff - school mean of violence experienced by non-LGB staff. The advantage of such a school indicator is that it allows for differences in degree of violence experienced between LGB staff and non-LGB staff at the same school, with all other circumstances being equal.

The individual score of feeling safe at school ranged 0-7 (sum of seven dichotomies: no / yes feeling safe in the classroom, study room or office, corridors, cafeteria, toilets, entry hall/locker area, and schoolyard). To support comparable analysis of school level scores on feelings of safety with the school level indicators on violence experienced, the original sumscore was converted to a scale of 0 to 100 for both staff and students. The value of the LGB school indicator on safety was then determined for each school by comparing the mean scores of the school's LGB staff members to the scores of its non-LGB staff members. Or: school indicator $=$ school mean of safety felt by LGB staff - school mean of safety felt by non-LGB staff. The same procedure was used to assess students' feeling unsafe at school. Comparing the results of LGB respondents versus those of non-LGB respondents at each school then results in four empirical indicators at the school level that are calculated separately for each school:

- Mean of severity of violence experienced by LGB staff compared with non-LGB staff at the same school;

- Mean of severity of violence experienced by LGB students compared with non-LGB students at the same school;

- Mean of extent to which LGB staff feel unsafe at school compared with non-LGB staff at the same school;

- Mean of extent to which LGB students feel unsafe at school compared with non-LGB students at the same school.

The interpretation of the scores or values of these school indicators is as follows:

- If an indicator's value is greater than zero, then LGB staff or LGB students experience more violence or feel less safe at school than non-LGB staff or non-LGB students;

- If an indicator's value is zero, then LGB staff or LGB students feel as safe at school as non-LGB staff or non-LGB students;

- If an indicator's value is less than zero, then LGB staff or LGB students experience less violence or feel safer at school than non-LGB staff or non-LGB students.

Table 5 gives an overview of the operationalization of the contextual school variables. The overview includes the variables' names, the organization or category of respondents with whom the variables were assessed, and a short description of their analysis or calculation.

Table 5 about here 


\section{Analysis at School Level}

First, univariate descriptive results will be presented for the four school level concepts of LGB discrimination for each year of measurement. Also, to answer the first part of the research question, differences between school indicators of LGB discrimination (means of LGB versus non-LGB staff and students) are calculated by using T-tests per year $(2006,2008$, 2010) and across years (2010 versus 2006 and 2010 versus 2008). Second, in answering the second part of the research question, Pearson correlation coefficients are used to estimate the relationships between the four LGB school indicators per year, within and between students and staff. Third, univariate descriptive outcomes are given for the contextual school variables and information is given about their statistical relationships with the four LGB indicators per year of assessment. This empirical information completes the answer to the research question. It should be noted that the numbers of schools in these analyses may differ somewhat from those in Table 1 because we had to account for differences in data selection and computation procedures across 2006 - 2010 (see further Mooij, Smeets et al., 2011).

\section{Results}

\section{LGB School Indicators, 2006-2010}

Univariate results on the scores of the four LGB school indicators are given in Table 6. The table gives the number of schools $(\mathrm{N})$ per research year with a valid value; the minimum and maximum school scores; the mean score (M); and the standard deviation (SD).

Table 6 about here

The mean values are all positive which shows that, in each case, LGB staff and LGB students experience relatively more violence and feel relatively less safe at school than non-LGB staff and non-LGB students. This applies to all three years concerned. In interpreting the means and differences in the experience of violence, we must take into account that the staff's scores can vary from 1 to 12 and students' scores from 1 to 23 .

Differences between LGB staff or students and non-LGB staff or students are presented in Table 7. The differences between the means for each year show, first of all, that LGB and non-LGB staff do not differ from one another in terms of severity of violence they report experiencing in 2008 and in 2010. The difference between 2008 and 2010 is also not statistically significant. For students, however, the difference between LGB students and nonLGB students in 2008 (5.91) and 2010 (7.49) is statistically significant; see Table 7. The two scores, 5.91 and 7.49, can be interpreted in terms of corresponding differences on the 23 scale items given in Table 3. In both years, LGB students experienced more violence at school than non-LGB students. There is also a statistically significant increase in the difference between LGB and non-LGB students (1.58) between 2008 and 2010; in 2010 the LGB discrimination score is higher than in 2008.

Table 7 about here 
Second, Table 7 shows that LGB staff feel less safe at school than non-LGB staff. This applies for all three years concerned. There are no significant changes in 2010 compared with 2008 or with 2006. For students, fairly large and significant differences exist between LGB and non-LGB students' feeling unsafe at school. In all three years, LGB students feel more unsafe than non-LGB students. Moreover, this difference increases significantly between 2008 and 2010 commensurate with the rise in students' reported experience of violence during this period (cf. Tables 6 and 7). There is no difference between 2010 and 2006 when it comes to LGB students' feeling unsafe, however.

In addition, Pearson correlations between the LGB school discrimination indicators reveal the significance of the relationships between LGB-related violence and LGB-related feeling unsafe; see Table 8. When LGB students experience more violence at school than non-LGB students, the LGB students at that school are also more likely than non-LGB students to feel unsafe. That is true in $2006(\mathrm{r}=0.40), 2008(\mathrm{r}=0.31)$, and $2010(\mathrm{r}=0.60)$. This phenomenon is not found among staff.

Table 8 about here

Furthermore, Table 8 reveals that there is no significant relationship between staff and student school indicators concerning LGB discrimination. In other words, when LGB students feel less safe at school than non-LGB students, this does not imply that LGB staff at the same school feel relatively less safe than non-LGB staff. The same result appears with respect to the school indicators for the reported LGB-related experience of violence.

\section{LGB School Indicators and Contextual School Variables}

Univariate descriptive analyses were conducted on the contextual school variables for 2006, 2008, and 2010. Then the relevance of these characteristics for the four LGB school indicators was explored by calculating contextual school mean differences and assessing Pearson correlation coefficients between the LGB indicators and the contextual school variables. All correlations were statistically non-significant, however.

\section{Discussion}

\section{Outcomes and Interpretations}

The information in Tables 6-8 demonstrates that the first part of the research question can be answered affirmatively: Yes, the degrees of violence experienced and feeling unsafe of LGB secondary students and LGB staff differ from those of non-LGB secondary students and nonLGB staff in the same school. The results clarify that LGB persons generally experience more violence and feel less safe than non-LGB persons in the same school. These differences were rather stable across 2006, 2008 and 2010. In addition, LGB discrimination against students is more problematic than is generally the case for teaching and support staff. Furthermore, the relationships between the LGB school indicators for violence and feeling unsafe were significantly related for students but not for staff. No significant relationships were present between indicators of students and staff. Finally, clear relationships between LGB school indicators and contextual school characteristics could not be established. 
In these findings, the within-school social interaction processes seem to differ for LGB students and staff. The possible significance of a school's social cohesion for all LGB students in a school is reflected, at the school level, in the stable and strong empirical relationships between the students' LGB indicators for violence and feeling safe in 2006, 2008, and 2010 (see Table 8). For staff, no statistically significant relationships exist between LGB experiences of violence and feeling unsafe in 2006, 2008, and 2010. The interpretation of this difference could be that a student who is discovering his or her gender and being nonconformist or LGB, and who is experimenting to elaborate or develop a more stable selfidentification as being LGB and trying to gain acceptance from peers and teachers as 'being different' from the heterosexual norm, will be influenced much by the various social, cultural, and behavioral qualities of the school's social cohesion or climate. A member of staff, however, will already be rather used to or convinced of his or her gender, and if he or she is non-conformist or LGB, will be concerned about or be forced to fight for within-school arrangements between personal identity and social identity and acceptance (cf. Dunn, 2012; Mooij \& Fettelaar, 2013a). Moreover, compared to an LGB student, acts of violence against an LGB staff member do not occur that often. These differences between personal relevance and social experiences of LGB students and LGB staff in the same school may then explain why no statistically significant relationships exist between the LGB school indicators for staff and students in 2006, 2008, and 2010.

These findings about the four LGB school indicators seem plausible and globally correspond to indications and outcomes found in other research (see the introduction section). With LGB students, however, we had to use an indirect operationalization of sexual orientation concerning students who experience violence in some way, excluding youth who are LGB but did not experience violence because of their sexual orientation and those who are not LGB and did not experience violence. This potential selection bias may increase the percentages of LGB students being victimized in the present study; with staff this potential bias does not occur. Furthermore, as this type of LGB school indicator study seems to be unique, the results cannot be compared directly with those of other research (e.g., Guasp, 2012; Hunt \& Jensen, 2007; Kosciw et al., 2012; Menning \& Holtzman, 2014; Toomey et al., 2012). The present results furthermore seem to indicate an increase in LGB discrimination at Dutch secondary schools between 2006-2010. However, these findings can be interpreted also by, for example, an increase in national educational policy and school attention for this discrimination issue (see the introduction) which has raised the corresponding awareness and, therefore, reporting levels (cf. also Dankmeijer, Koppers, \& Schouten, 2012; Mooij \& Fettelaar, 2013a). Future research with the NSSMS may improve the empirical clarity of this issue (see also Keuzenkamp, 2011).

An increase in national attention for LGBTQ issues may also be at stake concerning the findings with respect to the lack of relationships of LGB school indicators to contextual school variables. Schools vary in their degree of attention with a focus on LGB discrimination and the assessment of participation in GSA was limited to the year 2010. This short history of LGB focus and the cross-sectional assessment reduce the chances to capture statistical variation. Fetner and Kush (2008) show that participation in GSA programs must be clearly defined and continue at school for a sufficiently lengthy period of time (cf. also Lee. 2002; Van der Velden, no year; Walls et al., 2010).The longitudinal research of Guasp (2012) and 
Kosciw et al. (2012) also suggests that more, longer, more distributed, and more intense concentration on anti-LGB discrimination seems to work across years.

\section{Limitations and Improvements of the NSSMS}

A first limitation of the study is that we had to apply secondary analysis of available data which were not collected with a specific operationalization of gender non-conformity or LGBTQ in mind. The operationalization and analysis were, therefore, restricted to LGB persons. Moreover, data collection procedures demonstrated that the operationalization of LGBTQ with both staff and students will remain rather difficult in particular because the NSSMS is meant for all gender variations. The present outcomes of the LGB school indicators may therefore be influenced by the operationalization problems associated with assessing LGBTQ of staff and students. In 2012, we therefore introduced some direct questions in the NSSMS for students about each student's gender preference in general, the sexual orientation of the student's best friends and the student's liking of these friends. The goal is to understand this topic better and to improve operationalization of gender nonconformity.

A second limitation is the cross-sectional character of the assessment with students and staff, whereas assessment with schools is longitudinal but on a voluntary basis. A more thorough longitudinal design including assessment, concentrating on school intervention characteristics and assessment of educational, social, and behavioral characteristics at school, class, and student level, will theoretically and practically improve the empirical results (cf. Mooij, 2001, 2005). This issue has been proposed to the Dutch Ministry of Education, Culture and Science.

\section{Recommendations for Improving School Practice}

Within schools, specific social behavioral ways, institutional and pedagogical procedures, and cultural norms and patterns are related and may stimulate or reduce collaboration and prosocial practices between students and staff (cf. Beauvais \& Jenson, 2002; Carbines et al., 2006; Guasp, 2012; Harfitt, 2014; Kosciw et al., 2012; Perry \& Dyck, 2014; Toomey et al., 2012). Observation of lessons given by LGB people at secondary schools in the Netherlands on aspects of LGBTQ life reveals, for example, that personal coming-out stories have a positive social acceptance impact on a class of students if positioned within adequate didactic and curricular contexts (Mooij \& Fettelaar, 2013a). A positive social climate in a school will enable students' self-identification as being LGBTQ and their acceptance as "being different" from the heterosexual norm. For teachers and other staff, comparable positive cohesive processes of personal identity and social identity in school will then also be possible.

Increasing LGB-related safety at school may thus involve systematically examining school social cohesive characteristics including the following: establishing rules of prosocial behavior together with students and teaching staff, including sexual minority students and staff at the start of the school year and getting all to help monitor compliance with these rules; defining a clear school safety policy and strict enforcement of that policy for students and staff of all sexual orientations; using proper LGBTQ school indicators and diagnostics by longitudinal and normed criteria; regular empirical evaluation of LGBTQ school indicators by students, staff, and management; and consistency between preventative approaches at school, 
at home, and in the neighborhood (cf. also Chapman \& Harris, 2004; Chen, 2006; Dankmeijer et al., 2012; Mooij \& Fettelaar, 2013a, 2013b; Morin, 1974; Van Wormer \& McKinny, 2003).

Formulation of and guiding such a school development process is a main task of school management, who could use the information collected regularly by the NSSMS or another instrument. Therefore, a recommendation to further improve school practice is to incorporate the LGBTQ school indicators into the standard digital feedback NSSMS report sent to participating schools. These schools will then also receive information on the degree to which LGBTQ discrimination occurs at their school. After comparing their own school's scores to the national figures and comparing their own school's figures across time, schools can evaluate their own safety situation in two specific or double diagnostic ways and take specific action when necessary. A subsequent survey and feedback report will allow them to explore the new effects of such action or strategy.

However, from 2008-2010 we had several meetings with different schools and their management to discuss their NSSMS results and the double diagnostic analysis of their results as given in their feedback report. We also assisted in formulating a school safety policy on the basis of these concrete results. It turned out that schools do experience many problems in comprehending and using a feedback report and in particular a diagnostic approach to develop an effect-oriented school strategy to improve the social climate. We therefore refined the feedback report to the schools and informed the Ministry about further possibilities to support schools in using the outcomes of the NSSMS. Another recommendation is then to assist schools to optimally use the NSSMS and stimulate its potential effects in schools with both students and staff.

Finally, the results support further research on the improved operationalization of gender non-conformity with school staff and students. If longitudinal assessment with schools could be combined with longitudinal assessment with students, staff, and managers, improved assessment of LGBTQ school indicators could function in a theoretically causal school context. It would then be worthwhile to include information about, for example, ethnic or racial characteristics at individual and school levels, as these characteristics also seem relevant in LGBTQ-based social discrimination processes at school (Beauvais \& Jenson, 2002; Carbines et al., 2006; Mooij, 2011a, 2011b). A GSA type of approach as outlined above could then be designed and evaluated, to try to reduce LGBTQ discrimination and violence (cf. also Huebner, Rebchook, \& Kegeles, 2004; Mooij, 1999a, 1999b, 2005; Schuyf, 2009; Toomey et al., 2012).

\section{Declaration of Conflicting Interests}

The author declared no potential conflicts of interest with respect to the research, authorship, and/or publication of this article.

\section{Funding}

The secondary analyses were funded by the Dutch Ministry of Education, Culture and Science. The author received no financial support for writing, authorship, and publication of this article. 


\section{Acknowledgements}

The national school safety monitor survey (NSSMS) for secondary education was developed at the request of the Dutch Ministry of Education, Culture and Science, which consented to secondary analyses of the data and publication of the results. I am grateful to Daan Fettelaar MSc and drs. Wouter de Wit for their assistance in performing the data collection and necessary analyses and to Maureen Snow Andrade for her check of the appropriate use of English language.

\section{Biographical statement}

Ton Mooij functioned as a manager and researcher at ITS (Institute for Applied Social Sciences) of Radboud University, Nijmegen, the Netherlands. He holds a position as professor by special appointment for educational technology at Welten Institute (Research Centre for Learning, Teaching and Technology), Open Universiteit in the Netherlands. His research combines ICT-supported assessment and improvement of school processes including cognitive and social learning effects with pupils in primary and secondary education. Main topics of interest concern high ability of pupils; development of differentiated education and support for optimal cognitive and social learning in school practice; school safety and prevention of bullying and violence for both pupils and teachers in and around schools. He was awarded several prizes for his publications focusing on theory and experimental research on cognitive excellence in school practice. He furthermore conducted six national surveys into pupils' and teachers' social safety, bullying, and violence, in both primary and secondary education. Ton Mooij also investigated various school-based intervention possibilities to effectively prevent cognitive and social problem behaviour of pupils.

\section{References}

Beauvais, C., \& Jenson, J. (2002). Social Cohesion: Updating the State of the Research, CPRN Discussion Paper. Ottawa: Canadian Policy Research Networks.

Berrill, K. T. (1990). Anti-Gay violence and victimization in the United States: An overview. Journal of Interpersonal Violence, 5(3), 274-294.

Buijs, L., Hekma, G., \& Duyvendak, J. W. (2009). Als ze maar van me afblijven: Een onderzoek naar antihomoseksueel geweld in Amsterdam [They are not allowed to touch me: Research into anti-homosexual violence in Amsterdam]. Amsterdam: Amsterdam University Press.

Carbines, R., Wyatt, T., \& Robb, L. (2006). Encouraging tolerance and social cohesion through school education. Report to the Australian Government Department of Education, Science and Training. Erebus International. Retrieved from http://www.valueseducation.edu.au/verve/_resources/Encouraging_Tolerance_Final_Repor t.pdf

Caspersen, J., \& Raaen, F. D. (2014). Novice teachers and how they cope. Teachers and Teaching: theory and practice, 20(2), 189-211.

Chapman, C., \& Harris, A. (2004). Improving schools in difficult and challenging contexts: Strategies for improvement. Educational Research, 46(3), 219-228. 
Chen, K. (2006). Social skills intervention for students with emotional/behavioral disorders: A literature review from the American perspective. Educational Research and Reviews, 1(3), 143-149.

Cotten-Huston, A. L., \& Waite, B. M. (2000). Anti-homosexual attitudes in college-students: Predictors and classroom interventions. Journal of Homosexuality, 38(3), 117-133.

Dankmeijer, P. (1994). De organisatie van voorlichting over homoseksualiteit in Nederland. Verslag van een landelijke enquête over produktformulering[Organization of LGBT education in the Netherlands. Survey report about product formulation]. Amsterdam: Empowerment Lifestyle Services.

Dankmeijer, P. (2011). GALE Toolkit Working with Schools 1.0. Tools for school consultants, principals, teachers, students and parents to integrate adequate attention of lesbian, gay, bisexual and transgender topics in curricula and school policies. Amsterdam: GALE, The Global Alliance for LGBT Education. Retrieved from http://www.lgbt-education.info

Dankmeijer, P., Koppers, B., \& Schouten, M. (2012). Op school is iedereen aan zet. Goede voorbeelden: directeuren, docenten en leerlingen in Amsterdam integreren seksuele diversiteit (2007-2011) [At school everybody has to join. Good practices: management, teachers and students in Amsterdam integrate sexual diversity (2007-2011)]. Amsterdam: EduDivers.

De Boise, S. (2014). I'm not homophobic, "I've got gay friends": Evaluating the validity of inclusive masculinity. Men and Masculinities, first published on October 16. doi:10.1177/1097184X14554951

De Graaf, H., Van de Meerendonk, B., Vennix, P., \& Vanwesenbeeck, I. (2003). Beter voor de klas, beter voor de school: Werkbeleving en gezondheid van homo- en biseksuele mannen en vrouwen in het onderwijs [Improved teaching, better for school: Work experience and health of LGB men and women in education]. Retrieved from http://www.aob.nl/doc/Nl.pdf

Dunn, P. (2012). Men as victims: 'victim' identities, gay identities, and masculinities. Journal of Interpersonal Violence, 27(17), 3442-3467. doi: 10.1177/0886260512445378

Espelage, D. L., Aragon, S. R., \& Birkett, M. (2008). Homophobic teasing, psychological outcomes, and sexual orientation among high school students: What influence do parents and schools have? Psychology Review, 37(2), 202-216.

Felten, H. (2008). Als een homo op je valt...: Acceptatie van homoseksualiteit onder Utrechtse (hetero)jongeren [When a LGB person falls in love with you...: Acceptance of homosexuality with (heterosexual) youth in Utrecht]. Utrecht, The Netherlands: MOVISIE.

Ferfolja, T. (2010). Lesbian teachers, harassment and the workplace. Teaching and Teacher Education, 26, 408-414.

Fetner, T., \& Kush, K. (2008). Gay-Straight Alliances in high schools: Social predictors of early adoption. Youth \& Society, 40(1), 114-130.

Friesen, M. D., \& Besley, S. C. (2013). Teacher identity development in the first year of teacher education: A developmental and social psychological perspective. Teaching and Teacher Education, 36, 23-32.

Goldberg, N. G., \& Meyer, I. H. (2012). Sexual orientation disparities in history of intimate partner violence: Results from the California Health Interview Survey. Journal of Interpersonal Violence, 28(5), 1109-1118. doi: 10.1177/0886260512459384 
Gómez, A., Munte, A., \& Sorde, T. (2014). Transforming schools through minority males' participation: Overcoming cultural stereotypes and preventing violence. Journal of Interpersonal Violence, 29(1), 2002-2020.

Green, S., Dixon, P., \& Gold-Neil, V. (1993). The effects of a gay/lesbian panel discussion on college student attitudes toward gay men, lesbians, and persons with AIDS (PWAs). Journal of Sex Education and Therapy, 19(1), 47-63.

Gruenewald, J. (2012). Are anti-LGBT homicides in the United States unique? Journal of Interpersonal Violence, 27(18), 3601-3623. doi: 10.1177/0886260512462301

Guasp, A. (2012). The School Report: The experiences of gay young people in Britain's schools in 2012. London: Stonewall.

Han, S. C., Gallagher, M. W., Franz, M. R., Chen, M. S., Cabral, F. M., \& Marx, B. P. (2013). Childhood sexual abuse, alcohol use, and PTSD symptoms as predictors of adult sexual assault among lesbians and gay men. Journal of Interpersonal Violence, 28, 2505-2520.

Harel-Fisch, Y., Walsh, S. D., Fogel-Grinvald, H., Amitai, G., Pickett, W., Molcho, M., Due, P., Gaspar de Matos, M., \& Craig, W. (2011). Negative school perceptions and involvement in school bullying: A universal relationship across 40 countries. Journal of Adolescence, 34, 639-652.

Harfitt, G. J. (2014). Brokering dialogue between secondary students and teachers to coconstruct appropriate pedagogy in reduced-size classes. Teachers and Teaching: theory and practice, 20(2), 212-228.

Hebl, M. R., Bigazzi Foster, J., Mannix, L. M, \& Dovido, J. F. (2002). Formal and interpersonal discrimination: A field study of bias toward homosexual applicants. Personality and Social Psychology Bulletin, 28(6), 815-825.

Herzog, J. L., \& Rowley, R. L. (2014). My beliefs of my peers' beliefs: Exploring the gendered nature of social norms in adolescent romantic relationships. Journal of Interpersonal Violence, 29, 348-368.

Huebner, D. M., Rebchook, G. M., \& Kegeles, S. M. (2004). Experiences of harassment, discrimination, and physical violence among young gay and bisexual men. American Journal of Public Health, 94(7), 1200-1203.

Hunt, R., \& Jensen, J. (2007). The School Report: The experiences of young gay people in Britain's schools. London: Stonewall.

Inspectie van het Onderwijs [Inspectorate of Education]. (2009). Weerbaar en divers. Onderzoek naar seksuele diversiteit en seksuele weerbaarheid in het onderwijs [Resilient and diverse. Research into sexual diversity and sexual resiliency in education]. Utrecht, The Netherlands: Author.

Jackson, P. W. (1968). Life in classrooms. New York: Holt, Rhinehart and Winston.

Kamps, L. (2010). Intervention mapping: Hoe gaat het met de LHBT leerlingen op school? [Intervention mapping: How do LGBT students do at school?]. Amsterdam: EduDivers.

Kelley, K., \& Gruenewald, J. (in press). Accomplishing masculinity through anti-lesbian, gay, bisexual, and transgender homicide: A comparative case study approach. Men and Masculanities, published online before print September 182014.

Keuzenkamp, S. (2011). Acceptatie van homoseksualiteit in Nederland 2011. Internationale vergelijking, ontwikkelingen en actuele situatie [Acceptance of homosexuality in the Netherlands 2011. International comparison, developments and actual situation]. The Hague, The Netherlands: Sociaal en Cultureel Planbureau. 
Keuzenkamp, S., \& Oudejans, A. (2011). Gewoon aan de slag? De sociale veiligheid van de werkplek voor homoseksuele mannen en vrouwen [Work as usual? Social safety of the working place for homosexual men and women]. The Hague, The Netherlands: Sociaal en Cultureel Planbureau.

Kosciw, J. G., Greytak, E. A., Bartkiewicz, M. J., Boesen, M. J., \& Palmer, N. A. (2012). The 2011 National School Climate Survey: The experiences of lesbian, gay, bisexual and transgender youth in our nation's schools. New York: Gay, Lesbian and Straight Education Network (GLSEN).

Lee, C. (2002). The impact of belonging to a high school gay/straight alliance. The High School Journal, 85(3), 13-26.

Magnusson, D., \& Allen, V. L. (1983). Human development. An interactional perspective. New York: Academic Press.

Martino, W. (2000). Policing masculinities: Investigating the role of homophobia and heteronormativity in the lives of adolescent school boys. Journal of Men's Studies, 8(2), 213-236.

Mason, G. (1993). Violence prevention today: Violence against lesbian and gay men. Canberra: Australia Institute of Criminology.

McCormack, M., \& Anderson, E. (2010). 'It's just not acceptable any more': The erosion of homophobia and the softening of masculinity at an English sixth form. Sociology, 44(5), 843-859.

Menning, C. L., \& Holtzman, M. (2014). Processes and patterns in gay, lesbian, and bisexual sexual assault: A multimethodological assessment. Journal of Interpersonal Violence, 29, 1071-1093.

Mokken, R. J. (1997). Nonparametric models for dichotomous responses. In W. J. van der Linden en R. K. Hambleton (Eds.), Handbook of modern Item Response Theory (pp. 351367). New York: Springer.

Molenaar, I. W., \& Sijtsma, K. (2000). MSP5 for Windows: A program for Mokken Scale Analysis for polytomous items (Version 5.0). Groningen, The Netherlands: Rijksuniversiteit Groningen, ProGAMMA.

Mooij, T. (1994). Leerlinggeweld in het voortgezet onderwijs. Sociale binding van scholieren [Student violence in secondary education. Social cohesion of students]. Nijmegen: The Netherlands: Radboud Universiteit, ITS.

Mooij, T. (1999a). Promoting prosocial pupil behaviour: 1: A multilevel theoretical model. British Journal of Educational Psychology, 69(4), 469-478.

Mooij, T. (1999b). Promoting prosocial pupil behaviour: 2: Secondary school intervention and pupil effects. British Journal of Educational Psychology, 69(4), 479-504.

Mooij, T. (2001). Veilige scholen en (pro)sociaal gedrag. Evaluatie van de campagne 'De veilige school' in het voortgezet onderwijs [Safe schools and (pro)social behaviour. Evaluation of the campaign 'The safe school' in secondary education]. Nijmegen, The Netherlands: Radboud Universiteit, ITS.

Mooij, T. (2005). National campaign effects on secondary pupils' bullying and violence. British Journal of Educational Psychology, 75(3), 489-511.

Mooij, T. (2007). Discriminatie in en rond school [Discrimination in and around school]. Nijmegen, The Netherlands: Radboud Universiteit, ITS. 
Mooij, T. (2011a). Differences in pupil characteristics and motives in being a victim, perpetrator, and witness of violence in secondary education. Research Papers in Education, 26(1), 105-128.

Mooij, T. (2011b). Secondary school teachers' personal and school characteristics, experience of violence and perceived violence motives. Teachers and Teaching: theory and practice, 17(2), 227-253.

Mooij, T. (2012a). Personal, family, and school influences on secondary pupils' feelings of safety at school, in the school surroundings and at home. Teachers and Teaching: theory and practice, 18(2), 129-157.

Mooij, T. (2012b). A Mokken scale to assess secondary pupils' experience of violence in terms of severity. Journal of Psychoeducational Assessment, 30(5), 496-508.

Mooij, T. (2013). Designing education and learning for cognitively gifted pupils in preschool and primary school. International Journal of Inclusive Education, 17(6), 597-613.

Mooij, T. (in press). Relevance of student and contextual school variables in explaining a student's severity of violence experienced. Teachers and Teaching: Theory and Practice, 22(3). DOI: 10.1080/13540602.2015.1005864

Mooij, T., De Wit, W., \& Fettelaar, D. (2011). Sociale veiligheid in en rond scholen. Primair en Voortgezet Onderwijs 2006 - 2010 [Social safety in and around schools. Primary and Secondary Education 2006 - 2010]. Nijmegen, The Netherlands: Radboud Universiteit, ITS.

Mooij, T., De Wit, W., \& Polman, H. (2008). Sociale veiligheid in het Voortgezet (Speciaal) Onderwijs 2006 - 2008: Eindrapport [Social safety in Secondary (Special) Education 2006 - 2008: Final report]. Nijmegen, The Netherlands: Radboud Universiteit, ITS.

Mooij, T., \& Fettelaar, D. (2013a). Observatie van voorlichtingslessen seksuele diversiteit in het Voortgezet Onderwijs: Een pilot onderzoek [Observing education on sexual orientation in secondary school: A pilot]. Tijdschrift voor Orthopedagogiek, 52(6), 282-298.

Mooij, T., \& Fettelaar, D. (2013b). School and pupil effects on secondary pupils' feelings of safety in school, around school, and at home. Journal of Interpersonal Violence, 28(6), 1240-1265.

Mooij, T., Fettelaar, D., \& De Wit, W. (2012). Sociale onveiligheid van LHB schoolpersoneel en LHB leerlingen: Onderzoeksverslag [Social unsafety of LGB school staff and students: Research report]. Nijmegen, The Netherlands: Radboud Universiteit, ITS.

Mooij, T., Sijbers, R., \& Sperber, M. (2006). Rapportage Veiligheidsmonitor V(S)O [Report on the social safety survey Secondary (Special) Education]. Nijmegen, The Netherlands: Radboud Universiteit, ITS.

Mooij, T., \& Smeets, E. (2009). Towards systemic support of pupils with emotional and behavioural disorders. International Journal of Inclusive Education, 13(6), 597-616.

Mooij, T., Smeets, E., \& De Wit, W. (2011). Multi-level aspects of social cohesion of secondary schools and pupils' feelings of safety. British Journal of Educational Psychology, 81(3), 369-390.

Morin, S. F. (1974). Educational programs as a means of changing attitudes toward gay people. Homosexual Counseling Journal, 1(4), 160-165.

Perry, B., \& Dyck, D. R. (2014). Courage in the face of hate: A curricular resource for confronting anti-LGBTQ violence. In N. Chakraborti and J. Garland (Eds.), Responding to 
hate crime: The case for connecting policy and research (pp. 185-197). Bristol: The Policy Press.

Russell, S. T., Muraco, A., Subramaniam, A., \& Laub, C. (2009). Youth empowerment and high school gay-straight alliances. Springer, 38, 891-903.

Schouten, M. (2010). De LHBT voorlichtergroepen van Nederland [LGBT education groups in the Netherlands]. Amsterdam: COC NL \& EduDivers.

Schouten, M. (2011). De LHBT voorlichtergroepen van Nederland. Rapport 2010 in het kader van project 'Meer voorlichters, scholen, effect en inbedding' [LGBT education groups in the Netherlands. Report 2010 of the project 'More educators, schools, effect and impact']. Amsterdam: COC NL \& EduDivers.

Schuyf, J. (2009). Geweld tegen homoseksuele mannen en lesbische vrouwen: Een literatuuronderzoek naar praktijk en bestrijding [Violence against gay men and lesbian women: A review of the literature on practice and reduction]. Utrecht, The Netherlands: Movisie.

Tippett, N., Wolke, D., \& Platt, L. (2013). Ethnicity and bullying involvement in a national UK youth sample. Journal of Adolescence, 36, 639-649.

Toomey, R. B., McGuire, J. K., \& Russell, S. T. (2012). Heteronormativity, school climates, and perceived safety for gender nonconforming peers. Journal of Adolescence, 35, 187196.

Trotter, J. (2006). Violent crimes? Young people's experiences of homophobia and misogyny in secondary schools. Practice, 18(4), 291-302.

Valenti, M., \& Campbell, R. (2009). Working with youth on LGBT issues: Why gay-straight alliance advisors become involved. Journal of Community Psychology, 37(2), 228-248.

Van der Velden, C. (no year). Gay Straight Alliance. Een kwalitatief onderzoek naar de impact van GSA's op scholen in Nederland [Gay Straight Alliance. Qualitative research into the impact of GSA's at schools in the Netherlands]. Nationale Jeugdraad het Bureau; Retrieved from http://www.njrhetbureau.nl/images/pdf/rapportgsa.pdf

Van Wormer, K., \& McKinney, R. (2003). What schools can do to help gay/lesbian/bisexual youth: A harm reduction approach. Adolescence, 38(151), 409-420.

Walls, N. E., Kane, S. B., \& Wisneski, H. (2010). Gay-Straight Alliances and school experiences of sexual minority youth. Youth \& Society, 41(3), 307-332.

Willis, P. (1978). Learning to labour. Westmead, UK: Saxon House.

Yu, Y., Xiao, S., \& Liu, K. Q. (2013). Dating violence among gay men in China. Journal of Interpersonal Violence, 28, 2491-2504.

Zimmer-Gembeck, M. J., Nesdale, D., McGregor, L., Mastro, S., Goodwin, B., \& Downey, G. (2013). Comparing reports of peer rejection: Associations with rejection sensitivity, victimization, aggression, and friendship. Journal of Adolescence, 36, 1237-1246. 
School violence indicators of LGB students and staff

Table 1

Participation in the national school safety monitor survey (NSSMS), numbers per year

\begin{tabular}{ccccc}
\hline Year & Schools & Management & $\begin{array}{c}\text { Teaching and } \\
\text { support staff }\end{array}$ & Students \\
\hline 2006 & 214 & 629 & 6897 & 80790 \\
2008 & 219 & 606 & 6230 & 78840 \\
2010 & 140 & 470 & 5363 & 58369 \\
\hline
\end{tabular}




\section{Table 2}

Mokken Scale 'violence experienced by staff,' 2008 and 2010*

\begin{tabular}{|c|c|c|}
\hline Items & 2008 & 2010 \\
\hline 12. Rape & 01 & 00 \\
\hline 11. Using a weapon & 02 & 01 \\
\hline 10. Sexual molestation & 03 & 02 \\
\hline 9. Threatening with a weapon & 06 & 03 \\
\hline 8. Directed sexual contact or touching & 17 & 10 \\
\hline 7. Blackmailing & 29 & 20 \\
\hline 6. Hitting & 54 & 41 \\
\hline 5. Tripping on purpose & 56 & 45 \\
\hline 4. Jabbing on purpose & 56 & 46 \\
\hline 3. Bothering on purpose & 79 & 74 \\
\hline 2. Making a lot of noise on purpose & 85 & 81 \\
\hline \multirow{3}{*}{ 1. Talking in an extra loud voice } & 86 & 82 \\
\hline & 0.89 & 0.89 \\
\hline & 5727 & 4883 \\
\hline
\end{tabular}

* The figures in the 2008 and 2010 columns indicate the percentages of those who 'have experienced' the relevant item. 
School violence indicators of LGB students and staff

Table 3

Mokken Scale 'violence experienced by students' 2008 and 2010*

\begin{tabular}{|c|c|c|}
\hline Items & 2008 & 2010 \\
\hline 23. Rape & 04 & 03 \\
\hline 22. Using a weapon & 06 & 04 \\
\hline 21. Sexual molestation & 06 & 05 \\
\hline 20. Threatening with a weapon & 07 & 05 \\
\hline 19. Directed sexual contact or touching & 13 & 11 \\
\hline 18. Spray-painting or dirtying & 17 & 14 \\
\hline 17. Stealing & 18 & 15 \\
\hline 16. Beating or roughing up & 21 & 16 \\
\hline 15. Threatening & 22 & 17 \\
\hline 14. Intimidating & 24 & 20 \\
\hline 13. Destroying things & 25 & 20 \\
\hline 12. Scratching or damaging something & 31 & 26 \\
\hline 11. Sexual gestures & 32 & 29 \\
\hline 10. Hiding or mislaying something & 36 & 31 \\
\hline 9. Making sexual comments & 40 & 36 \\
\hline 8. Hitting & 44 & 38 \\
\hline 7. Tripping on purpose & 46 & 41 \\
\hline 6. Pushing or kicking on purpose & 51 & 45 \\
\hline 5. Striking or hurting on purpose & 54 & 49 \\
\hline 4. Making a lot of noise on purpose & 64 & 60 \\
\hline 3. Bothering on purpose & 65 & 60 \\
\hline 2. Talking in an extra loud voice & 66 & 61 \\
\hline \multirow{3}{*}{$\begin{array}{l}\text { 1. Calling someone names } \\
\text { Reliability Rho }\end{array}$} & 79 & 72 \\
\hline & 0.93 & 0.94 \\
\hline & 74260 & 55494 \\
\hline
\end{tabular}

* The figures in the 2008 and 2010 columns indicate the percentages of those who 'have experienced' the relevant item. 
School violence indicators of LGB students and staff

Table 4

Sexual orientation of teaching and support staff, according to year of assessment

\begin{tabular}{lrcrrrr}
\hline & \multicolumn{2}{c}{2006} & \multicolumn{2}{c}{2008} & \multicolumn{2}{c}{2010} \\
\cline { 2 - 7 } & $\mathrm{N}$ & $\%$ & $\mathrm{~N}$ & $\%$ & $\mathrm{~N}$ & \multicolumn{1}{c}{$\%$} \\
\hline Heterosexual & 6046 & 88.30 & 5284 & 86.28 & 4517 & 85.96 \\
Lesbian or gay & 101 & 1.48 & 106 & 1.73 & 72 & 1.37 \\
Bisexual & 65 & 0.95 & 62 & 1.01 & 34 & 0.65 \\
No answer & 635 & 9.27 & 672 & 10.97 & 632 & 12.03 \\
\hline
\end{tabular}


School violence indicators of LGB students and staff

\section{Table 5}

Operationalization of contextual school variables to explore LGBTQ discrimination

\begin{tabular}{|c|c|c|}
\hline Contextual school variables: & Assessed by / with: & School score indicated by: \\
\hline GSA (year 2010; 32 schools 'yes') & Dutch national LGBT-organization* & No - yes \\
\hline Mean experience of violence by staff & Staff: cf. indicator variable Table 4 & Mean per school (cf. Table 8) \\
\hline Mean experience of violence by students & Students: cf. indicator var. Table 5 & Mean per school (cf. Table 8) \\
\hline Mean of feeling safe by staff & Staff: cf. indicator variable & Mean per school (cf. Table 8) \\
\hline Mean of feeling safe by students & Students: cf. indicator variable & Mean per school (cf. Table 8) \\
\hline$\%$ of students high attainment (univ. Prep.) & Students: university : all particip. & $\%$ per school \\
\hline$\%$ of first grade students & Students: first grade : all particip. & $\%$ per school \\
\hline$\%$ of students who are religious & Students: self-report relig : not relig. & $\%$ per school \\
\hline School size (number of students) & School managers & Mean absolute number \\
\hline Policy to increase respect for LGB & School managers & $($ Mean of no/yes $) * 100$ \\
\hline
\end{tabular}

* This organization is "COC Netherlands" which has been advocating the rights of LGBT's from 1946 on. 
School violence indicators of LGB students and staff

\section{Table 6}

Univariate results for school level indicators of LGB discrimination, 2006, 2008, and 2010

\begin{tabular}{|c|c|c|c|c|c|c|c|c|c|c|c|c|}
\hline & \multicolumn{4}{|c|}{2006} & \multicolumn{4}{|c|}{2008} & \multicolumn{4}{|c|}{2010} \\
\hline & $\mathrm{N}^{*}$ & $\begin{array}{l}\text { Min.; } \\
\max .\end{array}$ & $\begin{array}{l}\text { Mean } \\
\text { across } \\
\text { schools }\end{array}$ & SD & $\mathrm{N}^{*}$ & $\begin{array}{l}\text { Min.; } \\
\text { max. }\end{array}$ & $\begin{array}{r}\text { Mean } \\
\text { across } \\
\text { schools }\end{array}$ & SD & $\mathrm{N}^{*}$ & $\begin{array}{l}\text { Min.; } \\
\max .\end{array}$ & $\begin{array}{r}\text { Mean } \\
\text { across } \\
\text { schools }\end{array}$ & SD \\
\hline Experience violence & & & & & & & & & & & & \\
\hline $\begin{array}{l}\text { Staff: school mean LGB } \\
\text { versus school mean non- } \\
\text { LGB }\end{array}$ & 6 & $\begin{array}{c}-1.56 \\
2.67\end{array}$ & 0.89 & 1.62 & 98 & $\begin{array}{l}-6.61 \\
6.08\end{array}$ & 0.10 & 2.34 & 65 & $\begin{array}{c}-4.31 \\
5.63\end{array}$ & 0.36 & 2.09 \\
\hline $\begin{array}{l}\text { Students: school mean } \\
\text { LGB versus school mean } \\
\text { non-LGB }\end{array}$ & 37 & $\begin{array}{c}0.07 \\
9.56\end{array}$ & 4.53 & 2.60 & 140 & $\begin{array}{l}-9.94 \\
14.39\end{array}$ & 5.94 & 4.70 & 89 & $\begin{array}{l}-8.00 \\
15.76\end{array}$ & 7.49 & 5.18 \\
\hline Feeling unsafe & & & & & & & & & & & & \\
\hline $\begin{array}{l}\text { Staff: school mean LGB } \\
\text { versus school mean non- } \\
\text { LGB }\end{array}$ & 93 & $\begin{array}{l}-11.79 \\
94.98\end{array}$ & 4.02 & 17.89 & 96 & $\begin{array}{l}-18.14 \\
84.00\end{array}$ & 4.11 & 16.34 & 68 & $\begin{array}{l}-11.59 \\
41.53\end{array}$ & 2.71 & 8.93 \\
\hline $\begin{array}{l}\text { Students: school mean } \\
\text { LGB versus school mean } \\
\text { non-LGB }\end{array}$ & 134 & $\begin{array}{c}-44.90 \\
96.86\end{array}$ & 26.98 & 33.82 & 140 & $\begin{array}{l}-59.18 \\
100.00\end{array}$ & 20.59 & 35.61 & 89 & $\begin{array}{l}-28.57 \\
95.99\end{array}$ & 31.03 & 33.69 \\
\hline
\end{tabular}

$* \mathrm{~N}=$ number of schools. 
School violence indicators of LGB students and staff

Table 7

Differences between means (T-tests) of school level indicators of LGB discrimination, per year and across years (number of schools in parentheses)

\begin{tabular}{|c|c|c|c|c|c|}
\hline & 2006 & 2008 & 2010 & $\begin{array}{l}\text { Difference } \\
2010-2006\end{array}$ & $\begin{array}{l}\text { Difference } \\
2010-2008\end{array}$ \\
\hline \multicolumn{6}{|l|}{$\begin{array}{l}\text { Experience of } \\
\text { violence }\end{array}$} \\
\hline $\begin{array}{l}\text { Staff: school } \\
\text { mean LGB versus } \\
\text { school mean non- } \\
\text { LGB }\end{array}$ & --- & ns (92) & ns (65) & --- & ns (157) \\
\hline $\begin{array}{l}\text { Students: school } \\
\text { mean LGB versus } \\
\text { school mean non- } \\
\text { LGB }\end{array}$ & --- & $5.91 * *(139)$ & $7.49 * *(89)$ & --- & $1.58 *(228)$ \\
\hline \multicolumn{6}{|l|}{ Feeling unsafe } \\
\hline $\begin{array}{l}\text { Staff: school } \\
\text { mean LGB versus } \\
\text { school mean non- } \\
\text { LGB }\end{array}$ & $4.02 *(93)$ & $3.27 *(95)$ & $2.71 *(68)$ & ns (161) & ns (163) \\
\hline $\begin{array}{l}\text { Students: school } \\
\text { mean LGB versus } \\
\text { school mean non- } \\
\text { LGB }\end{array}$ & $26.98 * *(134)$ & $20.91 * *(139)$ & $31.03 * *(89)$ & ns (362) & $10.12 *(228)$ \\
\hline
\end{tabular}


School violence indicators of LGB students and staff

\section{Table 8}

Pearson correlations between school level indicators of LGB discrimination for students and staff, per year (number of schools in parentheses)

\begin{tabular}{|c|c|c|c|c|c|c|}
\hline 2006 & \multicolumn{2}{|c|}{$\begin{array}{l}\text { Staff experience of } \\
\text { violence: LGB } \\
\text { versus non-LGB at } \\
\text { the same school }\end{array}$} & \multicolumn{2}{|c|}{$\begin{array}{l}\text { Student experience } \\
\text { of violence: LGB } \\
\text { versus non-LGB at } \\
\text { the same school }\end{array}$} & \multicolumn{2}{|c|}{$\begin{array}{l}\text { Staff feeling unsafe: } \\
\text { LGB versus non- } \\
\text { LGB at the same } \\
\text { school }\end{array}$} \\
\hline $\begin{array}{l}\text { Students' experience of violence: } \\
\text { LGB versus non-LGB }\end{array}$ & 0.80 & (3) & & & & \\
\hline $\begin{array}{l}\text { Staff feeling unsafe: } \\
\text { LGB versus non-LGB }\end{array}$ & -0.44 & (6) & 0.13 & (23) & & \\
\hline $\begin{array}{l}\text { Students feeling unsafe: } \\
\text { LGB versus non-LGB }\end{array}$ & 0.34 & (5) & $0.40^{*}$ & (37) & -0.05 & $(68)$ \\
\hline \multicolumn{7}{|l|}{2008} \\
\hline $\begin{array}{l}\text { Students' experience of violence: } \\
\text { LGB versus non-LGB } \\
\text { Staff feeling unsafe: } \\
\text { LGB versus non-LGB }\end{array}$ & 0.06 & $\begin{array}{l}(67) \\
(95)\end{array}$ & -0.20 & (66) & & \\
\hline $\begin{array}{l}\text { Students feeling unsafe: } \\
\text { LGB versus non-LGB }\end{array}$ & 0.03 & $(67)$ & $0.31^{* *} *$ & (139) & 0.07 & (66) \\
\hline \multicolumn{7}{|l|}{2010} \\
\hline $\begin{array}{l}\text { Students' experience of violence: } \\
\text { LGB versus non-LGB }\end{array}$ & 0.01 & $(46)$ & & & & \\
\hline $\begin{array}{l}\text { Staff feeling unsafe: } \\
\text { LGB versus non-LGB }\end{array}$ & 0.22 & (65) & -0.13 & (47) & & \\
\hline $\begin{array}{l}\text { Students feeling unsafe: } \\
\text { LGB versus non-LGB }\end{array}$ & 0.04 & (46) & $0.60^{* * *}$ & (89) & -0.25 & (47) \\
\hline
\end{tabular}

$* 0.01 \leq p \leq 0.05 ; * * p<0.01$. 